\title{
Growth, gas exchange and photochemical efficiency of the cowpea bean under salt stress and phosphorus fertilization
}

\author{
Francisco Vanies da Silva Sá ${ }^{1 *}$, Miguel Ferreira Neto' \\ Yuri Bezerra de Lima', Emanoela Pereira de Paiva', Rômulo Costa Prata', \\ Claudivan Feitosa Lacerda', Marcos Eric Baborsa Brito ${ }^{3}$ \\ 'Federal Rural University of the Semi-Arid, Mossoró, Brazil \\ ${ }^{2}$ Federal University of Ceará, Fortaleza, Brazil \\ ${ }^{3}$ Federal University of Sergipe, Nossa Senhora da Glória, Brazil \\ *Corresponding author, email: vanies_agronomia@hotmail.com
}

\begin{abstract}
Cowpea is widely cultivated in semiarid regions; however, these regions face serious problems with salinity of water and soil, thus constituting an abiotic stress that limits the development of this species. The objective of this study was to study the influence of phosphate fertilization on the morphophysiological components of cowpea plants irrigated with salinized water during the vegetative and reproductive phase. The research was carried out in a greenhouse from September to December 2015. A randomized complete block design with treatments arranged in a $5 \times 3$ factorial scheme with five replications was used. The factors consisted of the use of five levels of electrical conductivity of irrigation water: $0.5 ; 1.5 ; 2.5 ; 3.5$ and $4.5 \mathrm{dS} \mathrm{m}-1$ and three doses of phosphorus corresponding to $60 \%, 100 \%$ and $140 \%$ of the dose recommended for the culture that was $60 \mathrm{~kg}$ ha-1. The plants of cowpea cv. Paulistinha were cultivated in lysimeters with a capacity of $8 \mathrm{dm} 3$. At 30 and 49 days after sowing, periods corresponding to the vegetative (V4) and reproductive (V8 / R1) phases of the culture were evaluated gas exchange, chlorophyll fluorescence and growth. The increase in the electrical conductivity of the water reduced the growth, the photochemical activity and the phytomass accumulation of the cowpea plants, independent of the phenological phase. The higher dose of simple superphosphate increased the growth and photosynthetic activity of cowpea, mainly in the reproductive phase; Independent of the salinity of irrigation water.
\end{abstract}

Keywords: Vigna unguiculata, phosphorus, irrigation, salinity

Introduction

The cowpea is widely cultivated in semiarid regions, with emphasis on the Brazilian semiarid region, the main producing region of the world, where it is one of the main components of the diet in this region (LIMA et al., 2007). Nevertheless, the semi-arid region faces serious problems with water and soil salinity, a limiting factor for crop development, including cowpea, which tolerates irrigation with saline water of up to $3.3 \mathrm{dS} \mathrm{m}^{-1}$ and soil salinity (Ayers \& Westcot, 1999), and the available water sources, especially the underground ones, besides many agricultural areas of the region, may present salinity similar to or higher than these values (Medeiros et al., 2003). environmental stresses that negatively affect plant growth and metabolism attributed to the osmotic effect caused by the reduction of external water potential and to the ionic effect caused by the accumulation of ions in plant tissues (Esteves \& Suziki, 2008; Munns \& Tester, 2008; Taiz \& Zeiger, 2013). Among the negative effects promoted by saline stress, the reduction of photosynthetic activity stands out as one of the most limiting to the crops (Neves et al., 2009; Silva et al., 2014; Souza et al., 2011, Taiz et al., 2004), or to restrictions on photochemical activity, leading to reductions in the potential quantum efficiency of photosystem II (Praxedes et al., 2010; Silva et 
al., 2014; Souza et al., 2011).

Numerous practices aimed at mitigating the deleterious effects of saline stress in plants are being studied. Among these practices, we mention the management of fertilization using fertilizers that favor the absorption of nutrients by the plants in conditions of salinity (Silva et al., 2011). Phosphorus (P), an essential element for plants due to its performance in root growth, fruit maturation, grain formation, fruit and fiber formation and plant vigor, can be highlighted.

However, plants with P deficiency present low net photosynthetic rates, since phosphorus is the fundamental for this process to occur, as well as reductions in the number and size of the leaves, consequently in the photosynthetically active area. It is worth mentioning that phosphorus at adequate levels increases aerial dry matter production, pod number and seed mass in bean culture, being determinant in crop productivity, possibly due to the increase in the photosynthetic rate (Cruz et al., Zucareli et al., 2010).

The objective of this study was to study the influence of phosphate fertilization on the morphological and physiological components of cowpea plants irrigated with salinized water during the vegetative and reproductive phase.

\section{Material and Methods}

The research was carried out in a greenhouse of the Department of Environmental and Technological Sciences of the Federal Rural University of the Semi-Arid (UFERSA), in MossoróRN, from September to December 2015. The municipality of Mossoró-RN is located in the semi-arid region of northeastern Brazil and has geographical coordinates of $5^{\circ} 11$ ' south latitude, $37^{\circ} 20^{\prime}$ ' west longitude $\mathrm{Gr}$. and $18 \mathrm{~m}$ altitude.

The experiment was performed in a completely randomized design with treatments in a factorial arrangement $5 \times 3$ on five levels of saline water irrigation $\left(S_{1}=0.5 ; S_{2}=1.5 ; S_{3}=2.5 ; S_{4}=3,5 ; S_{5}\right.$ $\left.=4,5 \mathrm{dS} \mathrm{m}^{-1}\right)$, and three treatments of phosphate fertilization with simple superphosphate $\left(A_{1}\right.$ $=60 \%, A_{2}=100 \%$ and $A_{3}=140 \%$ of the dose recommended by Cavalcanti et al., 2008), with 5 replicates, totaling 75 experimental plots.

Phosphorus doses were calculated based on the results of the soil analysis and the nutritional requirement of the crop at the time of planting. The soil used in the experiment was taken from the A-horizon of an Alfisols RedYellow Latosol (EMBRAPA, 2013) located at the experimental farm of the UFERSA Campus in Mossoró. Soil samples were collected in the 0.0$30.0 \mathrm{~cm}$ layer and taken to the Laboratory of Soil, Water and Plant Analysis - LASAP, Federal Rural University of the Semi-Arid, to determine the physical and chemical attributes, following the methodology of EMBRAPA (2011) (Table 1).

For fertilization, the soil analysis and nutritional requirement of the crop were defined as established in the technical bulletin of fertilization recommendation for the state of Pernambuco (Cavalcanti et al., 2008). The fertilization recommendation for cowpea was $60 \mathrm{~kg} \mathrm{ha}^{-1}$ of $\mathrm{P}_{2} \mathrm{O}_{5} ; 20 \mathrm{~kg} \mathrm{ha}^{-1}$ of $\mathrm{K}_{2} \mathrm{O}$ and $50 \mathrm{~kg}$ $\mathrm{ha}^{-1}$ of $\mathrm{N}$ for one crop cycle, with a further $15 \mathrm{~kg}$ $\mathrm{ha}^{-1}$ of $\mathrm{Mg}$ as $\mathrm{MgSO}_{4}$. Based on the fertilization recommendation, the doses of $\mathrm{P}_{2} \mathrm{O}_{5}^{-}\left(\mathrm{A}_{1}=36, \mathrm{~A}_{2}\right.$ $=60$ and $A_{3}=84 \mathrm{~kg} \mathrm{ha}^{-1}$ ) were applied as single superphosphate $\left(A_{1}=0.7, A_{2}=1.17\right.$ and $A_{3}=1.64 \mathrm{~g}$

Table 1. Physical and chemical characteristics of a Red-Yellow Latosol Loamy Sand collected in the 0-30 cm layer, and of the cattle manure used in the cultivation of cowpea.

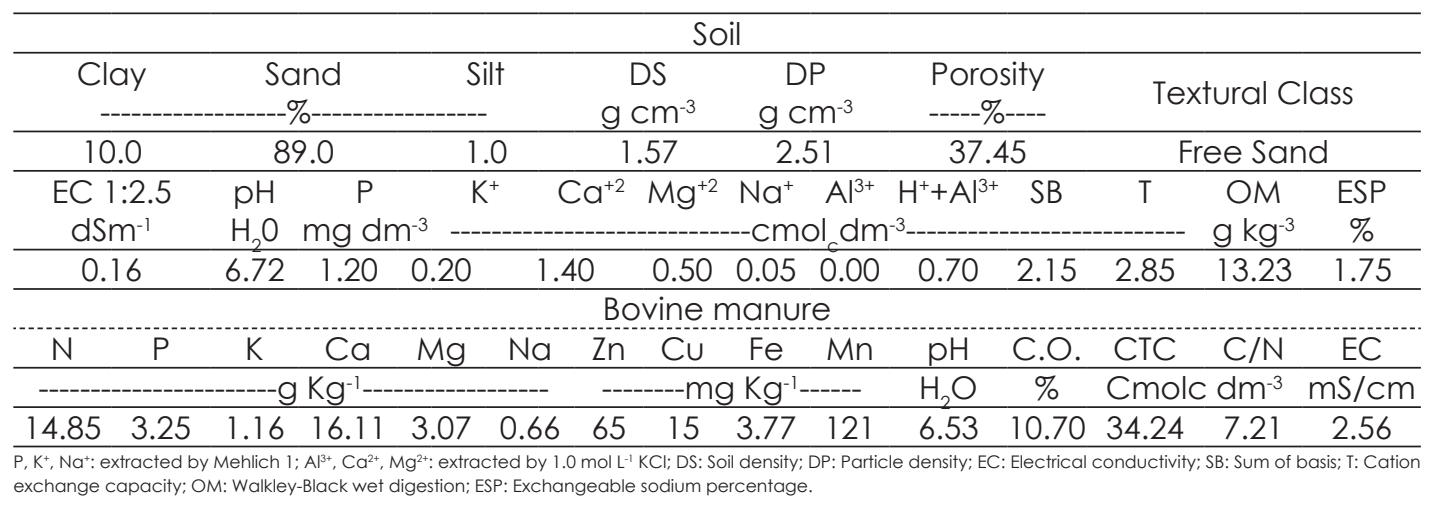


pot $^{-1}$ of $\mathrm{P}_{2} \mathrm{O}_{5}^{-}$), after which the soil was incubated for 20 days. Due to the sandy characteristics of the soil sample, the nitrogen and potassium fertilizations were applied in the cover, being nitrogenized at 14,21 and 27 days after sowing (DAS) and potassium fertilization applied at 28 and 35 DAS. The micronutrient requirement was met by its availability in the soil and by the application of $0.5 \mathrm{dm}^{3}$ of bovine manure.

The soil was conditioned in lysimeters with a capacity of $8 \mathrm{dm}^{3}$, of which $7 \mathrm{dm}^{3}$ was composed by the soil, $0.5 \mathrm{dm}^{3}$ was filled by bovine manure, being incorporated to the soil and $0.5 \mathrm{dm}^{3}$ per gravel in the lower part to facilitate the drainage. The lysimeters were filled in the following order: screen; gravel $2 \mathrm{dm}^{3}$ of soil; and the mixture of soil $\left(5 \mathrm{dm}^{3}\right)$, manure $\left(0.5 \mathrm{dm}^{3}\right)$ and the dose of $\mathrm{P}_{2} \mathrm{O}_{5}$ - calculated according to the treatment.

After soil preparation, irrigation was performed, leaving soil close to field capacity and subsequent irrigations were performed once a day to leave the soil with moisture close to the maximum retention capacity, based on the lysimeter method drainage, with the blade applied plus a leaching fraction of $20 \%$ every seven days. The applied volume (aV) per container was obtained by the difference between the previous lamina ( $\mathrm{pL}$ ) applied minus the drainage average (d), divided by the number of containers ( $\mathrm{n}$ ), as indicated in equation 1 :

$$
a V=\frac{p L(D / n)}{(1 \quad F L)} \quad \text { Eq. } 1
$$

The solution waters used in irrigation were prepared with the addition of sodium chloride $\mathrm{NaCl}$, which makes up $70 \%$ of salt ions in water sources used for irrigation in small properties in the Brazilian Northeast (Medeiros et al., 2003).

In the preparation of the irrigation water, with several saline concentrations, the equivalent ratio between the electrical conductivity of water (CEW) and the concentration of salts $(10 *$ meq $\mathrm{L}^{-1}=1 \mathrm{dS} \mathrm{m}^{-1}$ of (EW), extracted from Rhoades et al. (1992), valid for CEw of 0.1 to $5.0 \mathrm{dS} \mathrm{m}^{-1}$, in which the levels tested are included. In the preparation of the solutions, local supply water

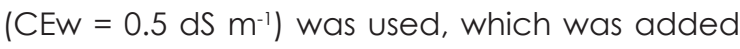
with salts as needed. After being prepared, the salinized water was stored in plastic containers of $150 \mathrm{~L}$, one for each level of CEw studied, duly protected, avoiding evaporation, the entrance of rainwater and the contamination with materials that could compromise its quality. To prepare the waters, with the appropriate EC, the salts were weighed according to the treatment, adding water until the desired level of EC was reached, and the values were obtained with a portable conductivity meter, which has its conductivity adjusted to a temperature of $25^{\circ} \mathrm{C}$.

After the first irrigation with the saline levels, sowing of cowpea cv. Paulistinha on October 14, 2015, using 10 seeds per pot. Fifteen DAS, with the total emergence of the seedlings, was thinned, leaving only three plants per pot.

At 30 and 49 DAS, regarding the vegetative phases (V4) and the beginning of the reproductive phase in the transition of the phases V8 and R1 of the culture, the cowpea plants were evaluated as the foliar gas exchanges, measured in the period from 8 to 10 hours of the morning. The evaluations were performed in the middle part of mature leaves, located between the $3^{\text {rd }}$ and $5^{\text {th }}$ leaf of each plant, counted from the apex, with a portable infrared analyzer of carbon dioxide (IRGA), model LI6400XT (Liquor, USA) with irradiation of $1500 \mu \mathrm{mol}$ photons $\mathrm{m}^{-2} \mathrm{~s}^{-1}$, air flow of $500 \mathrm{ml} \mathrm{min}^{-1}$ and under natural conditions of temperature and $\mathrm{CO}_{2}$ concentration. The following variables were obtained: $\mathrm{CO}_{2}$

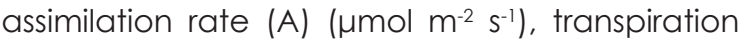
(E) (mmol of $\left.\mathrm{H}_{2} \mathrm{O} \mathrm{m}^{-2} \mathrm{~s}^{-1}\right)$, stomatal conductance (gs) $\mathrm{s}^{-1}$ ) and the internal $\mathrm{CO}_{2}$ concentration (Ci). The water efficiency (A/E) [( $\left.\mu \mathrm{mol} \mathrm{m}^{-2} \mathrm{~s}^{-1}\right)$ (mmol $\left.\mathrm{H}_{2} \mathrm{O} \mathrm{m}^{-2} \mathrm{~s}^{-1}\right)^{-1}$ ] and the instantaneous efficiency of carboxylation (A/Ci) were quantified (Silva et al., 2014).

Still in these leaves, foliar tweezers were placed and, after a period of $30 \mathrm{~min}$. $\left(F_{m}\right)$, fluorescence $\left(F_{m}\right)$, variable fluorescence $\left(F_{m}-F_{0}\right)$ and quantum efficiency of photosystem II $\left(\mathrm{F}_{\mathrm{v}} /\right.$ $F_{m}$ ) were determined (Silva et al., 2014), using the PEA-Hansatech equipment.

After physiological analysis, cowpea plants were evaluated for plant height $(\mathrm{PH})(\mathrm{cm})$, measured with the use of a graduated ruler, by the distance between the soil and the apex of the plants; the diameter of the stem (DS) (mm), 
measured with the use of a digital caliper in the lap of the plants to one centimeter of the soil; and the number of leaves (NL), from the count of the mature leaves. At the end of the growth analyzes, the aerial part of one of the plants was collected, separating the leaves and the stem, which were conditioned in paper bags and later placed in an air circulating oven at $65^{\circ} \mathrm{C}$, for drying the material until they reached constant weight and then were weighed in an analytical balance with an accuracy of $0.0001 \mathrm{~g}$, obtaining the dry mass of the shoot (MSPA) (g).

The data were submitted to analysis of variance by the ' $\mathrm{F}$ ' test up to the $5 \%$ probability level, in the cases of significance, polynomial regression analyzes were performed for the salinity factor of the irrigation water, and for the phosphate fertilization factor was applied the Tukey averages test, both at the $5 \%$ probability level, with the aid of the statistical software $\operatorname{SISVAR}^{\circledast}$ (Ferreira, 2011).

\section{Results and Discussion}

Vegetative phase

A linear decreasing behavior was observed in the growth of the bean plants during the vegetative phase, with reductions of $0.7 \mathrm{~cm}$ in height, $0.15 \mathrm{~mm}$ of stem diameter and 0.4 leaves, for each increase of $1.0 \mathrm{dS} \mathrm{m}^{-1}$ in irrigation water salinity (Figure 1A, C and E). The results indicate that the accumulation of salts in the soil had a negative influence on the growth of cowpea plants, possibly due to the osmotic effects caused by the accumulation of salts and the ionic interactions caused by excess salts of sodium chloride in the soil, which affects the availability, absorption, transport, assimilation and distribution of nutrients by the plant, promoting reductions in plant growth (Neves et al., 2009). Lima et al. (2007) and Silva et al. (2009), evaluating the tolerance of cowpea plants under salinity conditions, also observed reductions in growth with increasing salinity of irrigation water, which attribute the effect to morphophysiological changes, especially the transpiration, which leads to a reduction in the growth in number of leaves and cell elongation, which may have occurred in this work, and can be confirmed when the gas exchange data are verified.
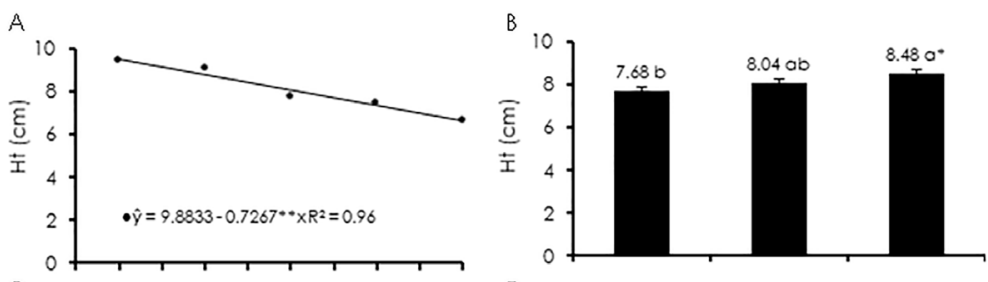

C

D
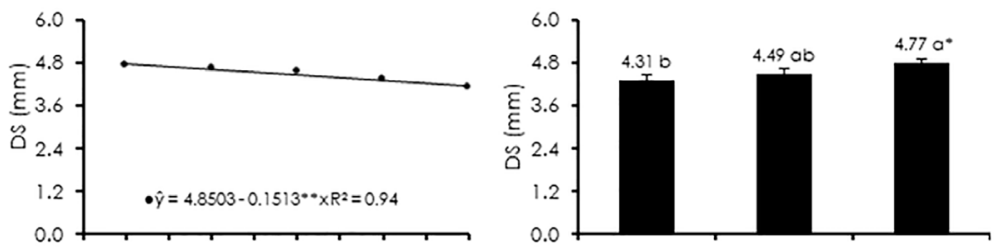

E

$\mathrm{F}$

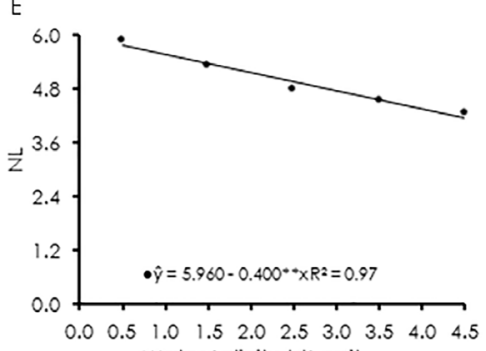
Water Salinity ( $\left.\mathrm{d} S \mathrm{~m}^{-1}\right)$

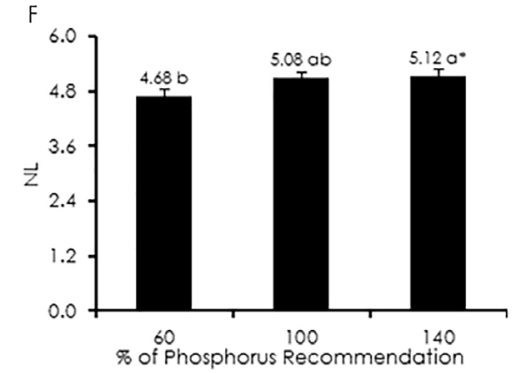

** = significant at $1 \%$ probability $(p<0.01)$. Equal letters do not differ from the Tukey test at the $5 \%$ probability level

Figure 1. Height $(\mathrm{Ht})(\mathrm{A}$ and $\mathrm{B})$, diameter of the stem (DS) (C and $\mathrm{D}$ ) and number of leaves (NL) (E and F) of cowpea plants $\mathrm{cV}$. Paulistinha under different saline water levels and phosphate fertilization $\left(A_{1}=60, A_{2}=100 \%\right.$ and $A_{3}=140 \%$ of the $P_{2} O_{5}$ recommendation) in the vegetative phase ( 30 days) 
It can be observed in Figures 1B, D and $F$ that even when irrigating with saline water, phosphate fertilization above the recommended dose for the cultivation provided the growth of the cowpea plants, increasing 9.4, 9.6 and 8.5 $\%$ for height, diameter and number of leaves, respectively, during the first 30 days of cultivation. This shows that phosphate fertilization stimulated the growth of cowpea plants independent of the salinity conditions studied (Figure 1B, D and F). Results similar to those observed by Oliveira et al. (2010), who observed that the higher availability of phosphorus increased the number of leaves of the radish plants, regardless of the salinity studied.

The gaseous exchange variables of the cowpea plants decreased linearly as a function of the saline increase of the irrigation water, except for the water use efficiency, in which quadratic behavior was observed (Figure 2E). There was a reduction of $45.22 \%$; $60.00 \%$; $43.02 \%$; $10.71 \%$ and $39.06 \%$, for the variables: $\mathrm{CO}_{2}$ assimilation rate, transpiration, stomatal conductance, internal $\mathrm{CO}_{2}$ concentration and instantaneous carboxylation efficiency, respectively, when the

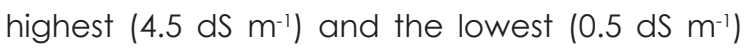
level of electrical conductivity of the applied water (Figure 2A, B, C, D, F). The reductions in the gas exchange activity observed in this work are possibly related to the osmotic effect, which acts on the water relations of the plant, reducing the cellular content promoting retraction and relaxation of the cell membrane (Taiz \& Zeiger, 2013).

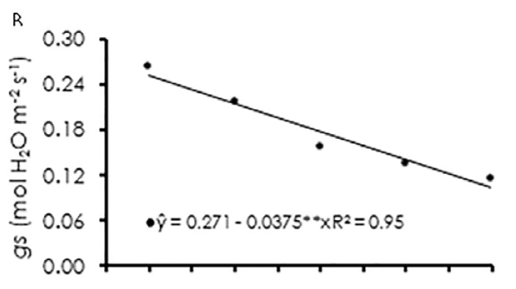

$\mathrm{D}$

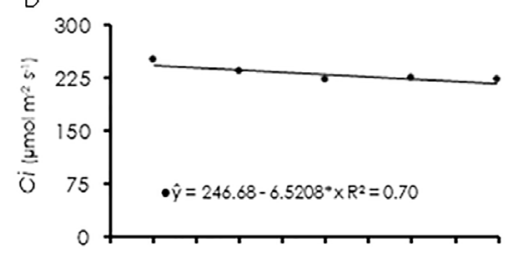

$\mathrm{F}$

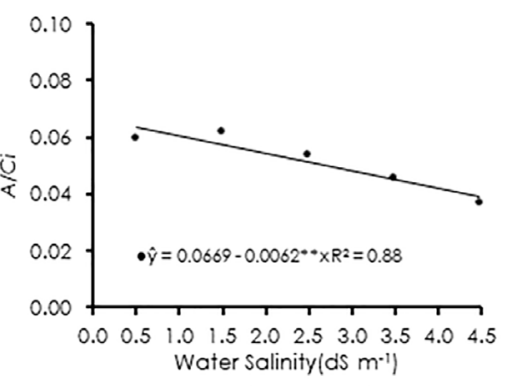

Figure 2. $\mathrm{CO}_{2}$ assimilation rate (A), transpiration (E) (B), stomatal conductance (gs) (C), internal $\mathrm{CO}_{2}$ concentration (Ci) (D), water use efficiency (wUE) (E) and instantaneous efficiency of the carboxylation (A/Ci) (F) of cowpea plants $\mathrm{c}$. Paulistinha under different saline water levels and phosphate fertilization $\left(A_{1}=60, A_{2}=100 \%\right.$ and $A_{3}=140 \%$ of the $P_{2} O_{5}$ recommendation) in the vegetative phase (30 days after sowing)

The expression of the osmotic effect acts on the stomatal activity, promoting the closure of the stomata and consequently reductions in the transpiration rate, in the internal $\mathrm{CO}_{2}$ concentration by reducing the influx of $\mathrm{CO}_{2}$ into the cell, thereby compromising photosynthetic activity. As was observed in this study, Neves et al. (2009) and Souza et al. (2011) working with cowpea plants under conditions of saline stress, also observed that the stomatal closure directly limited the photosynthetic activity of the plants. Further, it is confirmed by the theory that the 
reduction in the growth of the cowpea plants were related to the reduction in perspiration, as mentioned.

In relation to the carboxylation efficiency, $\mathrm{A} / \mathrm{Ci}$, there was also a reduction with increased salinity, a variable that expresses the relationship between the consumption and the availability of $\mathrm{CO}_{2}$ in the sub stomatal cavity. Thus, the reduction of $\mathrm{A} / \mathrm{Ci}$ is related to non-stomatal factors such as RuBisCO enzyme activity, possibly altered due to disturbances of metabolic processes, since the interactions promoted by specific ions such as $\mathrm{NaCl}$ affect the absorption, assimilation and transport of nutrients in the functions of the plasma membrane and in the disorders of metabolic processes, such as protein synthesis, enzyme activity, respiration and photosynthesis (Esteves \& Suzuki, 2008, Syvertsen \& García-Sánchez, 2014).

It was verified that the greater efficiency in the use of water, when the plants of cowpea were irrigated with saline water at $2.45 \mathrm{dS} \mathrm{m}^{-1}$, reaching the maximum efficiency of 2,03 [ $(\mu \mathrm{mol}$ $\left.\left.\mathrm{CO}_{2} \mathrm{~m}^{-2} \mathrm{~s}^{-1}\right)\left(\mathrm{mmol} \mathrm{H} \mathrm{H}_{2} \mathrm{~m}^{-2} \mathrm{~s}^{-1}\right)^{-1}\right]$, decreasing its efficiency at levels higher than this (Figure 2E). This result indicates that cowpea plants tried to adapt to saline stress conditions, however, the pressure exerted by stress at levels higher than this directly affected the physiology of the plant. Possibly the high accumulation of salts in the soil, restricted the availability of water to the plants, considering that the loss of water by the plants is regulated by the activity of the guard-cells. In addition, the stomatal closure contributes to the reduction of the $\mathrm{CO}_{2}$ assimilation rate, since there are restrictions in the chloroplast activity due to the lower availability of $\mathrm{CO}_{2}$ in the environment (Ferraz et al., 2012; Silva et al., 2014).

Also on the gas exchanges, a significant influence of the phosphate fertilization was observed under the cowpea plants, so that the plants that received more phosphorus obtained higher rates of $\mathrm{CO}_{2}$ assimilation, greater stomatal conductance and transpiration rates, and instantaneous efficiency of the carboxylation, independent of the salinity level studied (Figure $3 A, B, C$ and $D)$.
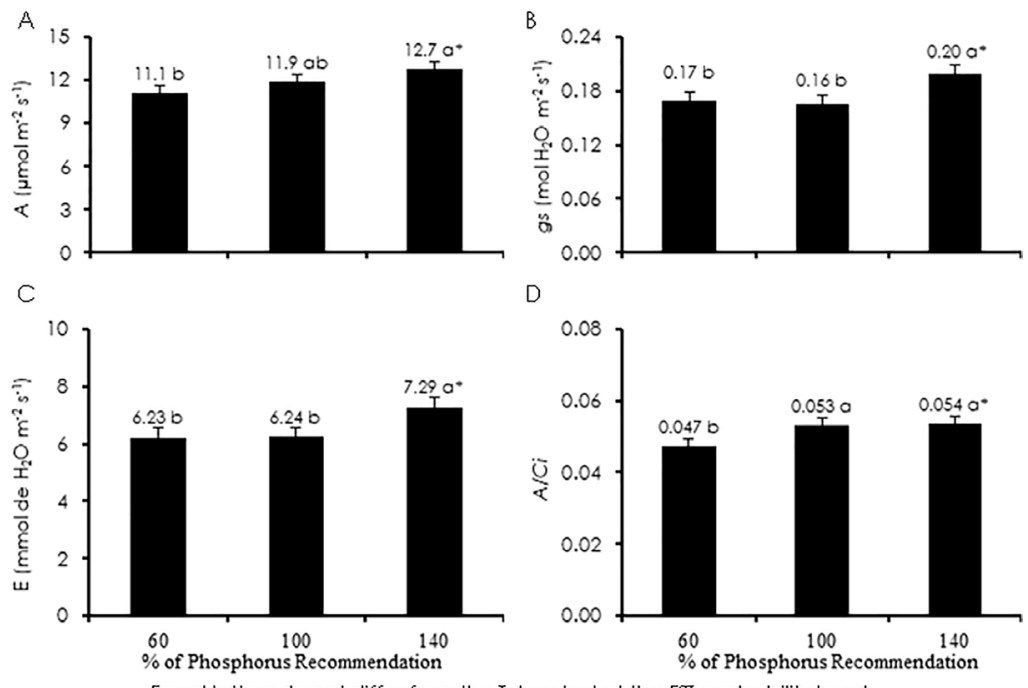

D

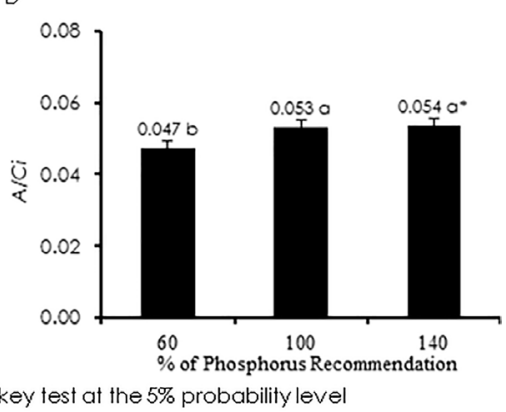

Figure 3. Rate of assimilation of $\mathrm{CO}_{2}(A)(A)$, transpiration (E) (B), stomatal conductance (gs) (C) and instantaneous efficiency of carboxylation (A/Ci) cowpea cv. Paulistinha under different saline water levels and phosphate fertilization $\left(A_{1}=60, A_{2}=100 \%\right.$ and $A_{3}=140 \%$ of the $P_{2} O_{5}$-recommendation) in the vegetative phase (30 days after sowing)

The reduction of $P$ uptake by the plant may lead to decreases in the consumption and production of ATP and NADPH, lower carboxylation/regeneration of Ribulose 1,5 bisphosphate carboxylase oxygenase, decrease in the expression of genes related to photosynthesis (Machado et al. 2010, Silva et al.,
2014), changes that may have been verified at the lowest $\mathrm{P}$ dose, thus limiting plant growth, as verified.

As for chlorophyll a fluorescence, there was an increasing linear behavior of the initial flowering (Fo) of the cowpea plants with the augmentation in salinity of the irrigation water 
(Figure 4A). According to Zanandrea et al. (2006), the adapted state to the dark is a situation in which the sheet is photochemically inactive, i.e., where all the electron transport processes in the thylakoid membrane are deactivated, resulting in a minimal trans-thylakoid gradient and very low concentrations of NADPH and ATP, thus allowing the achievement of maximum efficiency values for the photochemical processes of photosynthesis. Thus, the initial fluorescence explains the energy

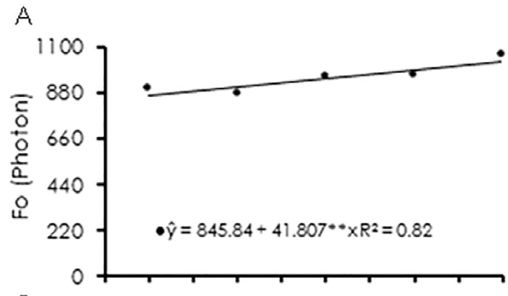$$
\text { C }
$$

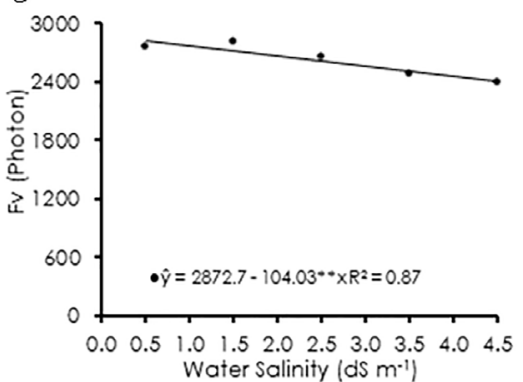

dissipated when all the electron exchange sites of photosystem II are at rest, therefore, the increase of $F_{0}$ indicates loss of light energy due to damages to the photosynthetic apparatus of the plant, a fact that may be related to the losses in the photosynthetic activity with increased saline stress, which is consistent with gas exchange analyzes, since a reduction in the intrinsic efficiency of carboxylation (A/Ci) was identified.

B
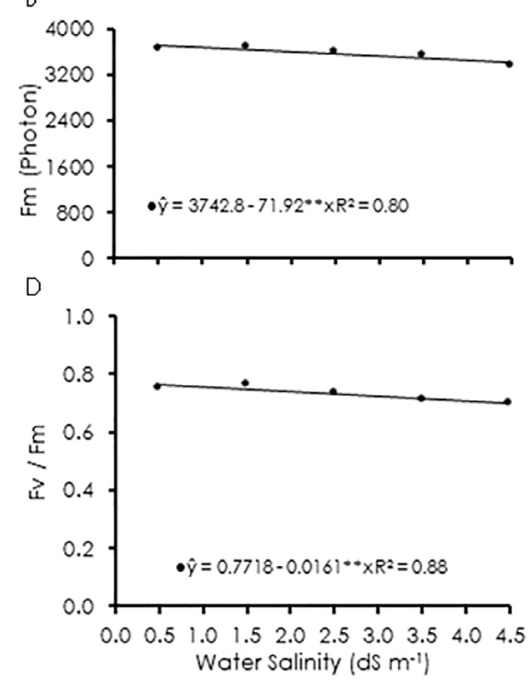

$* *=$ significant at $1 \%$ probability $(p<0.01)$

Figure 4. Fluorescence initial $\left(F_{o}\right)(A)$, maximum fluorescence $\left(F_{m}\right)(B)$, variable fluorescence $\left(F_{v}\right)(C)$ and quantum efficiency of photosystem $\|\left(F_{v} / F_{m}\right)$ cowpea $c v$. Paulistinha under different saline water levels and phosphate fertilization $\left(A_{1}=60, A_{2}=100 \%\right.$ and $A_{3}=140 \%$ of the $\mathrm{P}_{2} \mathrm{O}_{5}-$ recommendation) in the vegetative phase (30 days after sowing)

On the chlorophyll a fluorescence, linear reductions of the maximum fluorescence, variable and quantum efficiency of photosystem II were observed in the order of 71.92 (photons), 104.03 (photons) and $0.016 \%$, respectively, for each unit increase of salinity on irrigation water (Figure 1B, C and D). The observed changes in $F_{\circ}$ (initial fluorescence) and $F_{m}$ (peak fluorescence) are relative to the situation where the acceptor QA is reduced, since the rate of the competitor reoxidation of QA by the pool of plastoquinone is lower than the rate of reduction of the (Zanandrea et al., 2006). Therefore, the reductions in $F_{m}$ and $F_{v}$ together with the increase

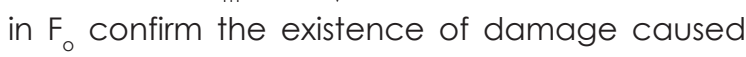
by the photosynthetic apparatus in the plant, possibly due to the reduction of the acceptor $Q A$, causing damage to photosystem II. It was observed that quantum yield indexes were mostly lower than 0.75 , which indicates malfunctioning of the same, caused by the photo protection mechanism, reducing the energy pressure in the photosystems under conditions of excess energy (Machado et al. 2010; Silva et al., 2014).

The results observed in the physiological activity and in the growth of the cowpea plants had repercussions on the accumulation of phytomass, with linear reductions with increased salinity (Figure 5A). Considering that the phytomass reflects the actual accumulation of carbohydrates generated in the photosynthesis, the reduction of the photosynthetic activity caused by the saline stress directly affected the accumulation of phytomass of the cowpea plants.

On the other hand, the plants that received higher doses of phosphorus obtained greateraccumulation of phytomass, independent of the salinity studied (Figure 5B). Under conditions of higher availability of phosphorus, the greater 


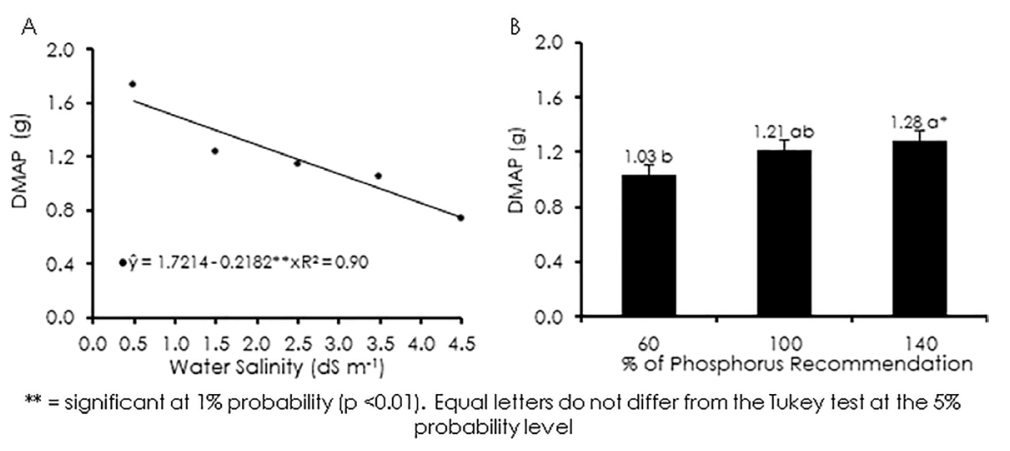

Figure 5. Dry mass of aerial part, DMAP (A and $B$ ) of cowpea plants $c v$. Paulistinha under different saline irrigation level and phosphate fertilization $\left(A_{1}=60, A_{2}=100 \%\right.$ and $A_{3}=140 \%$ of the $\mathrm{P}_{2} \mathrm{O}_{5}^{-}$recommendation) in the vegetative phase ( 30 days after sowing).

accumulation of phytomass of plants may be related to the essentiality of phosphorus to the plant, being a structural and biochemical component, besides promoting stimuli in the photosynthetic activity. Therefore, the plants that received less phosphorus, besides being limited in nutrient absorption by the osmotic effect, still had a higher energy expenditure due

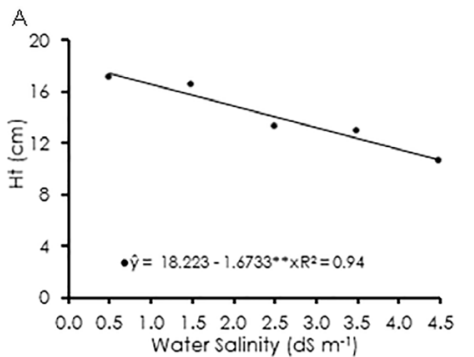$$
\text { C }
$$

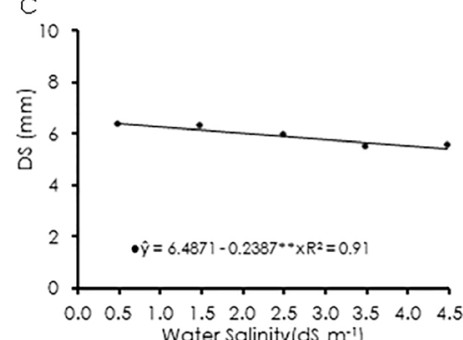
Water Salinity (ds $\left.\mathrm{m}^{-1}\right)$ to reduced phosphorus content in the medium. However, there was no interaction between salinity and phosphorus in the physiological and growth variables during the vegetative stage of the cowpea. Thus, the increase in dry matter accumulation is mainly related to the better nutritional condition of the plant.

** = significant at $1 \%$ probability $(p<0.01)$. Equal letters do not differ from the Tukey test at the $5 \%$ probability level

Figure 6. Height $(\mathrm{H}+)_{\text {) }}(\mathrm{A}$ and $\mathrm{B}$ ), diameter of the stem (DS) (C and D) and number of leaves (NL) (E and F) of cowpea plants $\mathrm{CV}$. Paulistinha under different saline irrigation level and phosphate fertilization $\mathrm{A}_{1}=60, \mathrm{~A}_{2}=100 \%$ and $\mathrm{A}_{3}=140 \%$ of the $\mathrm{P}_{2} \mathrm{O}_{5}^{-}$recommendation) in the reproductive phase (49 days after sowing)

Reproductive Phase

The growth of the cowpea in the reproductive phase was similar to that observed in the growth phase, with linear reductions in height, stem diameter and number of leaves of the plants (Figure 6A, C and D). In relation to phosphate fertilization, the highest growth of plant height was obtained when the highest

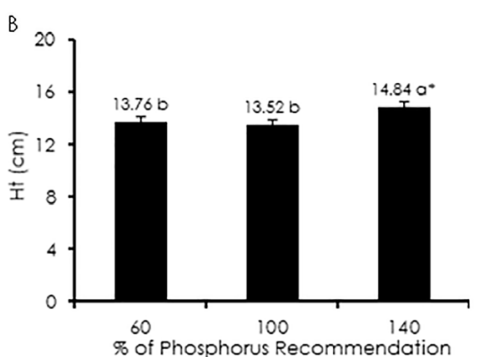

D

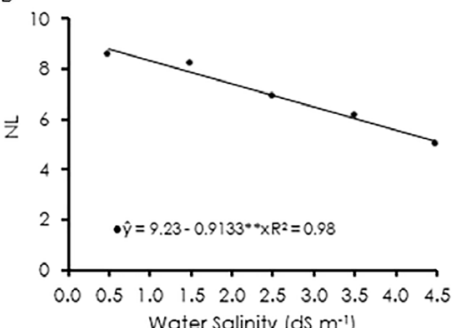
Water Salinity (ds $\mathrm{m}^{-1}$ ) dose of superphosphate was fertilized, regardless of the level of salinity evaluated (Figure 6B). Possibly, phosphate fertilization increased the vigor of cowpea plants, denoting that the nutritional response of phosphate fertilization reverts to the reproductive phase of the crop, even when submitted to salinity, in the other variables there were no differences between the 
doses of phosphorus applied.

The photosynthetic activity of the cowpea plants decreased as a function of the increase of salinity of the irrigation water,

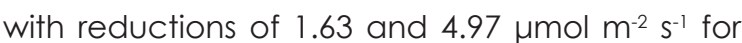
fertilization management $A_{2}$ and $A_{3}$ respectively, for each unit of water salinity. However, no significant adjustment of the equations for plants
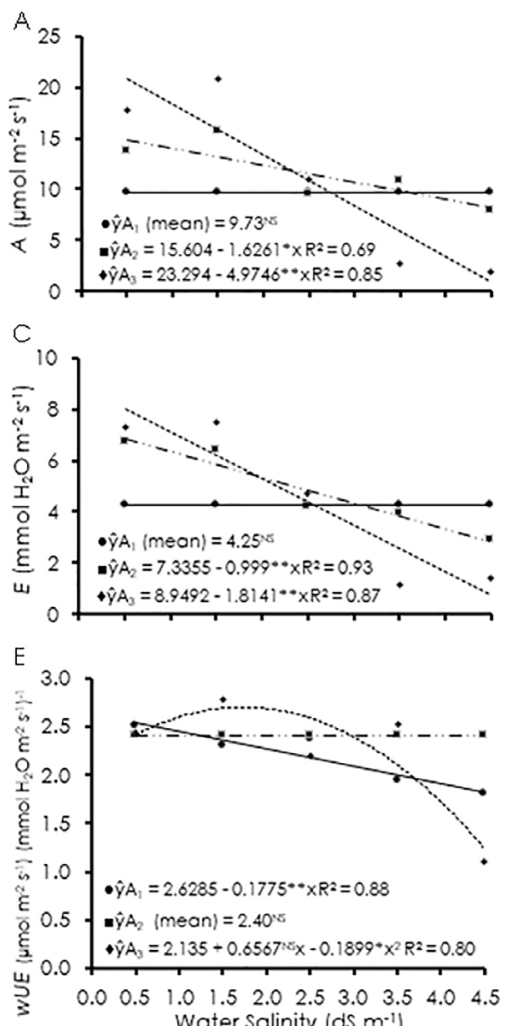

$N S, *$ and ${ }^{* *}=$ non-significant $(p>0.05)$, significant at 5 and $1 \%$ probability $(p<0.5$ and $p<0.01)$, respectively

Figure 7. $\mathrm{CO}_{2}$ assimilation rate (A), transpiration (E) (B), stomatal conductance (gs) (C), internal $\mathrm{CO}_{2}$ concentration (Ci) (D), water use efficiency (WUE) (E) and instantaneous efficiency of the carboxylation (A/Ci) (F) of cowpea plants CV. Paulistinha under different saline irrigation level and phosphate fertilization $\left(A_{1}=60, A_{2}=100 \%\right.$ and $A_{3}=140 \%$ of the $\mathrm{P}_{2} \mathrm{O}_{5}$-recommendation) in the reproductive phase (49 days after sowing)

With the results observed in the growth and gas exchange, it is noticed that the response of cowpea to phosphate fertilization varies according to the stress condition of the plant. Therefore, not stressed plants respond more to increase the availability of ' $P$ ', possibly related to better nutritional balance and essentiality of the nutrient, as noted in the vegetative stage of the crop. While stressed plants do not respond to phosphate fertilization, they can even obtain lower results than those that receive less phosphorus at the higher salinity level, probably due to the release of calcium and sulfur from simple superphosphate, thereby increasing soil cultivated under $A_{1}$ management was observed, with an average of $9.73 \mu \mathrm{mol} \mathrm{m} \mathrm{m}^{-2} \mathrm{~s}^{-1}$ of $\mathrm{CO}_{2}$ liquid assimilation. It is also observed that the plants cultivated in the $\mathrm{A}_{3}$ management obtained the highest photosynthetic rates under the lowest salinity levels, however, with a gradual increase in water salinity, these plants drastically reduced their photosynthetic activity (Figure 7A).
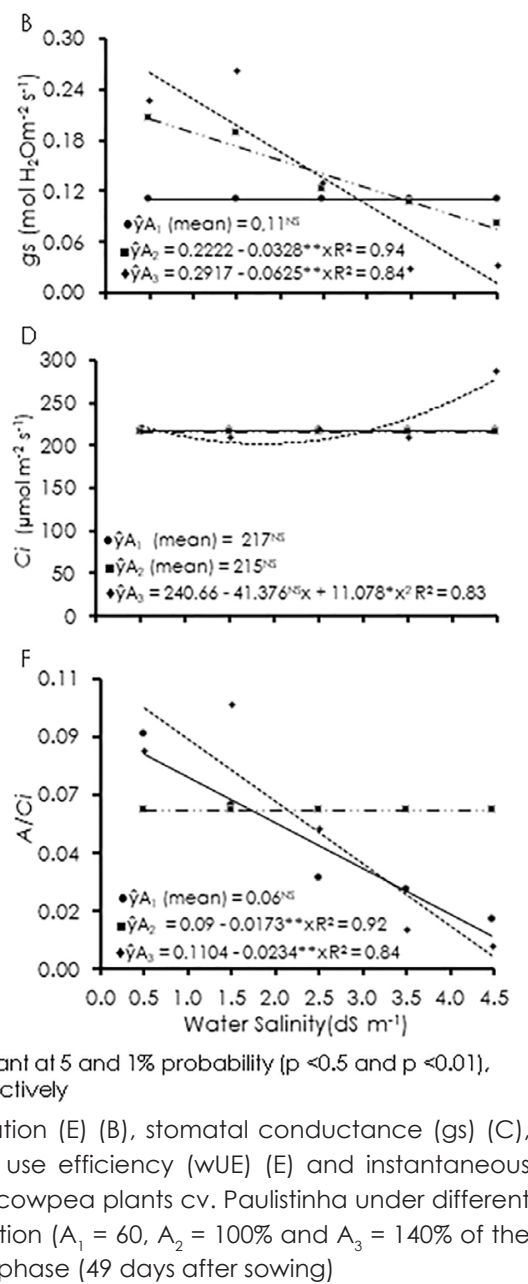

salinity. Similar results were observed in sorghum plants by Lacerda et al. (2006), evaluating the interaction between phosphorus and salinity, the authors also verified that sorghum plants (bicolor Sorgum) stressed did not respond to the application of $\mathrm{P}$ and even had a small decrease in growth at the highest level of this essential element.

The reductions in the photosynthetic activity of cowpea plants were drastically reduced as a function of stomatal activity, which decreased in proportion to the rate of $\mathrm{CO}_{2}$ and transpiration assimilation, reaching relatively low levels at the highest salinity levels studied (3.5 and 
$4.5 \mathrm{dS} \mathrm{m}^{-1}$ ) (Figure $7 \mathrm{AB}$ and $\mathrm{C}$ ), when compared to the common ones in $\mathrm{C}_{3}$ plants (Taiz \& Zeiger, 2013). It was also observed that the restriction of the gas exchange activity was so drastic that the reduction of the photosynthetic activity in the higher levels of salinity promoted an increase of the internal $\mathrm{CO}_{2}$ concentration, as observed in the $\mathrm{A}_{3}$ management plants, probably due to the malfunction of the activity of the enzyme Ribulose 1,5-bisphosphate carboxylase oxygenase (RuBisCO) (Fugura 7D).

The water use efficiency of the cowpea plants under $A_{3}$ management was augmented with increasing salinity of the irrigation water up to the level of $1.73 \mathrm{dS} \mathrm{m}^{-1}$, with a wUE of 2.7 ( $\mu \mathrm{mol}$ $\left.\mathrm{m}^{-2} \mathrm{~s}^{-1}\right)\left(\mathrm{mmol} \mathrm{H} \mathrm{O} \mathrm{m}^{-2} \mathrm{~s}^{-1}\right)^{-1}$, decreasing from this level of water salinity, indicating that cowpea plants tried to adapt to saline stress by increasing their photosynthetic activity and/or by restricting the transpiratory rate. There was also a linear reduction in the wUE of the cowpea plants that

received less phosphorus $\left(A_{1}\right)$ as a function of the increase in water salinity (Figure 7E). Considering that phosphorus is bound, or regulates starch/ sucrose biosynthesis, it regulates the activation of RUBisCO and the energy supply in ATP for the Calvin cycle (Sá et al., 2015; Marques et al., 2016), the higher phosphorus supplementation conferred the cowpea plants greater tolerance to salinity, possibly the best nutrition of the plant.

For the chlorophyll a fluorescence, there was an increase in the initial flowering rates of the cowpea plants as a function of the increase of irrigation water salinity (Figure 8A). It was also observed linear reductions of the maximum fluorescence, variable and quantum efficiency of photosystem II in the order of 271 (photon), 358.6 (photon) and 0.066, respectively, for each increase of $1.0 \mathrm{dS} \mathrm{m}^{-1}$ in salinity of irrigation water (Figure 8 B, C and D), regardless of the dose of ' $P$ ' used.

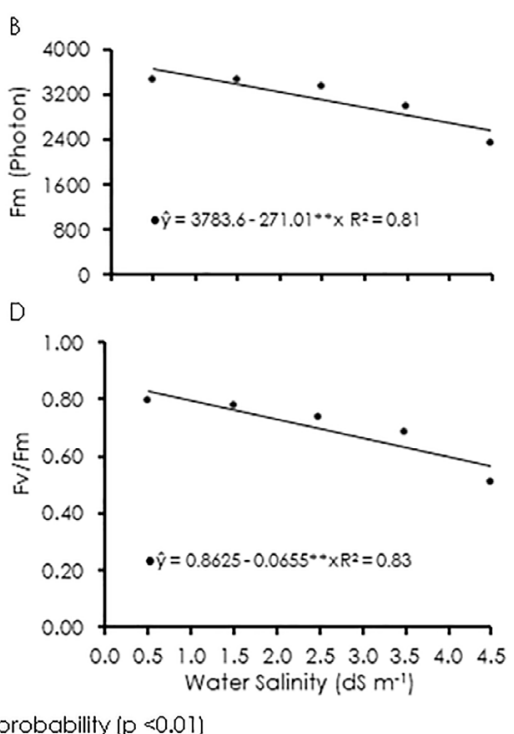

Figure 8. Fluorescence initial $\left(F_{o}\right)(A)$, maximum fluorescence $\left(F_{m}\right)(B)$, variable fluorescence (Fv) (C) and quantum efficiency of photosystem $\|\left(F v / F_{m}\right)$ cowpea $c v$. Paulistinha under different saline irrigation level and phosphate fertilization $\left(A_{1}=60, A_{2}=100 \%\right.$ and $A_{3}=140 \%$ of the $\mathrm{P}_{2} \mathrm{O}_{5}$-recommendation) in the reproductive phase (49 days after sowing)

The increase of the initial fluorescence associated to the reductions in the maximum fluorescence are indications of damages in the photosynthetic apparatus, since saline stress promotes changes in the structures of the thylakoids of the chloroplasts making them disorganized, consequently affecting the molecules of chlorophyll (Esteves \& Suzuki, 2008). These effects cause low yields in variable fluorescence, luminous energy available for performing of photosynthetic activity, which in turn reduce the quantum yield of chlorophyll $a$, compromising photosynthetic activity (Praxedes et al., 2010; Silva et al., 2014; Souza et al. al., 2011 ), as was also verified in this study.

Moreover, damage to the photosynthetic apparatus observed were consistent with those observed in the vegetative phase, which may 
be related to the effect on the efficiency of carboxylation, which was reduced by increasing salinity in this situation, it is added that, besides caused osmotic effect due to the increase in salinity, ionic effect can be observed, with limitation of the activity of photosystem II, mainly when the electrical conductivity of water was

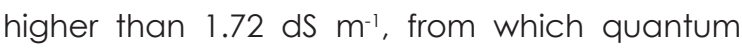
efficiency values of the photosystem II lower than 0.75 , value that indicates a malfunction in the apparatus (Silva et al., 2004).

The dry mass of the aerial part of the cowpea plants decreased linearly with the increase of the salinity of the irrigation water, independent of the phosphate fertilization (Figure 9). It can be observed, therefore, that the reductions in aerial biomass accumulation, independent of the crop phase, corroborate with observed decreases in photosynthetic activity, denoting the severity of saline stress over the plants, the toxicity potential of $\mathrm{NaCl}$ ions, affecting the physiology, growth and nutritional responses of the plant (Esteves \& Suzuki, 2008; Munns \& Tester, 2008; Syvertsen \& GarcíaSánchez, 2014).

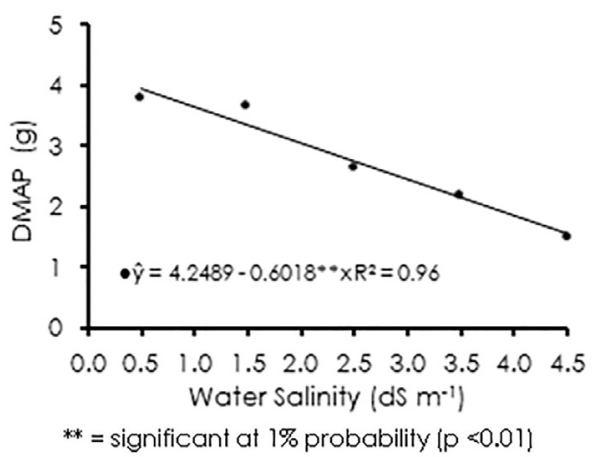

Figure 9. Dry mass of the aerial part (DMAP) of beanCaupi cv. Paulistinha under different saline water leves and phosphate fertilization $\left(A_{1}=60, A_{2}=100 \%\right.$ and $A_{3}=140 \%$ of the $P_{2} O_{5}-$ recommendation) in the reproductive phase (49 days after sowing)

\section{Conclusions}

Increased salinity of irrigation water reduced growth, photochemical activity, and phytomass accumulation of cowpea plants.

The higher doses of phosphorus resulted in higher vegetative growth and improvements in physiological responses, but these effects were independent of the salinity of the irrigation water.

The increase of phosphorus doses increased the photosynthetic activity of cowpea plants.

Phosphate fertilization did not influence the chlorophyll a fluorescence of cowpea plants.

The progressive effect of saline stress is more harmful on the growth and physiology of cowpea in the reproductive phase.

\section{Acknowledgements}

Capes for granting the master's degree scholarship and the National Institute of Science and Technology in Salinity for research funding and CNPq for research productivity grants.

\section{Referências}

Ayers, R.S., Westcot, D.W. 1999. A qualidade de água na agricultura. 2.ed. Campina Grande: UFPB, 153p. FAO Irrigação e Drenagem.

Cavalcanti, F.J.A., Santos, J.C.P, Pereira, J.R., Leite, J.P., Silva, M.C.L., Freire, F.J., Sousa, A.R., Messias, A.S., Faria, C.M.B., Burgos, N., Lima Junior, M.A., Gomes, R.V., Cavalcanti, A.C., Lima, J.F.W.F. 2008. Recomendações de adubação para o Estado de Pernambuco. $2^{a}$ Aproximação. Recife - Instituto Agronômico de Pernambuco IPA, 212p. II.

Cruz, J.L., Souza Filho, L.F.S., Pelacani, C.R. 2015. Influência da adubação fosfatada sobre $\mathrm{O}$ crescimento do camapu (Physalis angulata L.). Revista Brasileira de Plantas Medicinais 17: 360366.

EMBRAPA. 2011. Manual de métodos de análise do solo. 3. ed. Rio de Janeiro: Centro Nacional de Pesquisa de Solos, 230 p.

EMBRAPA. 2013. Sistema brasileiro de classificac,ão de solos. 3. ed. Brasília: Centro Nacional de Pesquisa de Solos, 353p.

Esteves, B.S., Suzuki, M.S. 2008. Efeito da salinidade sobre as plantas. Oecologia Brasiliensis 12: 662679.

Ferraz, R.L.S., Melo, A.S., Suassuna, J.F., Brito, M.E.B., Fernandes, P.D., Nunes Júnior, E.S. 2012. Trocas gasosas e eficiência fotossintética em ecotipos de feijão-Caupi cultivados no semiárido. Pesquisa Agropecuária Tropical 42: 181-188.

Ferreira, D.F. 2011 . Sisvar: a computer statistical analysis system. Ciência e Agrotecnologia 35: 1039-1042.

Furtado, G.F., Soares, L.A.A., Sousa, J.R.M., Andrade, E.M.G., Guerra, H.O.C. 2013. Alterações fisiológicas em feijão-caupi irrigado com água salina e adubação nitrogenada. Revista Verde de Agroecologia e Desenvolvimento Sustentável 8: 175-181. 
Henry, A., Chopra, S., Clark, D.G., Lynch, J.P. 2012. Responses to low phosphorus in high and low foliar anthocyanin coleus (Solenostemon scutellarioides) and maize (Zea mays). Functional Plant Biology 39: 255-265.

Lacerda, C.F., Morais, H.M.M., Prisco, J.T., Gomes Filho, E., Bezerra, M.A. 2006. Interação entre salinidade e fósforo em plantas de sorgo forrageiro. Revista Ciência Agronômica 37: 258263.

Lima, C.J.G.S., Oliveira, F.A., Medeiros, J.F., Oliveira, M.K.T., Almeida Júnior, A.B. 2007. Resposta do feijão-Caupi a salinidade da água de irrigação. Revista Verde de Agroecologia e Desenvolvimento Sustentável 2: 79-86,

Machado, D.F.S.P., Machado, E.C., Machado, R.S., Ribeiro, R.V.2010. Efeito da baixa temperatura noturna e do porta-enxerto na variação diurna das trocas gasosas e na atividade fotoquímica de laranjeira 'Valência'. Revista Brasileira de Fruticultura 32: 351-359.

Marques, D.J., Silva, E.C., Ferreira, M.M., Paglis, C.M., Souza, T.C., Maluf, W.R., Maciel, G.M., Ferreira, E.D., Lobato, A.K.S. 2016. Differential responses of root system and gas exchange in contrasting tomato genotypes under phosphorus starvation. Australian Journal of Crop Science 10: 101-110.

Medeiros, J.F., Lisboa, R.A., Oliveira, M., Silva Júnior, M.J. , Alves, L.P. 2003. Caracterização das águas subterrâneas usadas para irrigação na área produtora de melão da Chapada do Apodi. Revista Brasileira Engenharia Agrícola e Ambiental 7: 469-472.

Munns, R., Tester, M. 2008. Mechanism of salinity tolerance. Annual Review of Plant Biology 59: 651-681.

Neves, A.L.R., Lacerda, C.F., Guimarães, F.V.A., Gomes Filho, E., Feitosa, D.R.C. 2009. Trocas gasosas e teores de minerais no feijão-de-corda irrigado com água salina em diferentes estádios. Revista Brasileira de Engenharia Agrícola e Ambiental 13: 873-881.

Oliveira, F.R.A., Oliveira, F.A.O., Medeiros, J.F., Sousa, V.F.L., Freire, A.G. 2010. Interação entre salinidade e fósforo na cultura do rabanete. Revista Ciências Agronômica 41: 519-526.

Praxedes, S.C., Lacerda, C.F., Damatta, F.M. Prisco, J.T., Gomes-Filho, E. 2010. Salt tolerance is associated with differences in ion accumulation, biomass allocation and photosynthesis in cowpea cultivars. Journal of Agronomy and Crop Science 196: 193-204.

Prazeres, S.S., Lacerda, C.F., Barbosa, F.E.L., Amorim, A.V., Araújo, I.C.S., Cavalcante, L.F.
2015. Crescimento e trocas gasosas de plantas de feijão-Caupi sob irrigação salina e doses de potássio. Revista Agro@mbiente 9: 111-118.

Rhoades, J.D., Kandiah, A., Mashali, Q.M. 1992. The use of saline waters for crop production. Rome: FAO, 133p. (Irrigation and Drainage Paper, 48).

Sá, F.V.S., Brito, M.E.B., Silva, L.A., Moreira, R.C.L., Fernandes, P.D., Figueiredo, L.C. 2015. Fisiologia da percepção do estresse salino em híbridos de tangerineira - Sunki Comum sob solução hidropônica salinizada. Comunicata Scientiae, 6: 463-470.

Silva, F.E.O., Maracajá, P.B., Medeiros, J.F., Oliveira, F.A., Oliveira, M.K.T. 2009. Desenvolvimento vegetativo do feijão-Caupi irrigado com água salina em casa de vegetação. Revista Caatinga 22: 156-159.

Silva, F.L.B., Lacerda, C.F., Sousa, G.G., Neves, A.L.R., Silva, G.L., Sousa, C.H.C. 2011. Interação entre salinidade e biofertilizante bovino na cultura do feijão-de-corda. Revista Brasileira de Engenharia Agrícola e Ambiental 15: 383-389.

Silva, L.A., Brito, M.E.B., Sá, F.V.S., Moreira, R.C.L., Soares Filho, W.S., Fernandes, P.D. 2014. Mecanismos fisiológicos de percepção do estresse salino de híbridos de porta-enxertos citros em cultivo hidropônico. Revista Brasileira de Engenharia Agrícola, 18: S1-S7,

Souza, R.P., Machado, E.C., Silveira, J.A.G., Ribeiro, R.V. 2011. Fotossíntese e acúmulo de solutos em feijão-Caupi caupi submetido à salinidade. Pesquisa Agropecuária Brasileira, 46: 586-592.

Syvertsen, J.P., Garcia-Sanchez, F. 2014. Multiple abiotic stresses occurring with salinity stress in citrus. Environmental and Experimental Botany 103: 128-137.

Taiz, L., Zeiger, E. 2013. Fisiologia vegetal. 5. ed. Porto Alegre: Artmed, 918p.

Zanandrea, I., Nassi, F.L., Turchetto, A.C., Braga, E. J.B., Peters, J.A., Bacarin, M.A. 2006. Efeito da salinidade sob parâmetros de fluorescência em Phaseolus vulgaris. Revista Brasileira de Agrociência 12: 157-161.

Zucareli, C., Ramos Junior, E.U., Oliveira, M.A., Cavariani, C., Nakagawa, J. 2010. Índices biométricos e fisiológicos em feijão-Caupi sob diferentes doses de adubação fosfatada. Semina: Ciências Agrárias 31: 1313-1324. 